\title{
Neglected aspects of tick-borne rickettsioses
}

\author{
Laura Tomassone ${ }^{1 *}$, Aránzazu Portillo², Markéta Novákováa,4, Rita de Sousa ${ }^{5}$ and José Antonio Oteo ${ }^{2}$
}

\begin{abstract}
Rickettsioses are among the oldest known infectious diseases. In spite of this, and of the extensive research carried out, many aspects of the biology and epidemiology of tick-borne rickettsiae are far from being completely understood. Their association with arthropod vectors, the importance of vertebrates as reservoirs, the rarity of clinical signs in animals, or the interactions of pathogenic species with rickettsial endosymbionts and with the host intracellular environment, are only some examples. Moreover, new rickettsiae are continuously being discovered. In this review, we focus on the 'neglected' aspects of tick-borne rickettsioses and on the gaps in knowledge, which could help to explain why these infections are still emerging and re-emerging threats worldwide.
\end{abstract}

Keywords: Rickettsia spp., Ticks, Vertebrate hosts, Candidatus, Epidemiology

\section{Background}

Rickettsioses, infections caused by bacteria from the family Rickettsiaceae, are among the oldest known infectious diseases and are mainly transmitted by arthropod vectors [1]. The most clinically severe tick-borne rickettsiosis [2], the Rocky Mountain spotted fever, was firstly described in 1899, and ten years later Ricketts showed that the Rocky Mountain wood tick, Dermacentor andersoni, was vector of the causative agent of the disease [3, 4]. For approximately nine decades, Rickettsia rickettsii had been the only tick-borne rickettsia associated with human disease in the New World and several rickettsiae from this region were considered non-pathogenic. Similar patterns, with one known pathogenic rickettsial species and various species of unknown pathogenicity, had been observed in Europe and Africa (Rickettsia conorii conorii), Asia (Rickettsia sibirica) and Australia (Rickettsia australis) [2, 5].

In the past 30 years, with advent of molecular techniques, the range of known species within this group of bacteria raised significantly. Numerous rickettsial species continue to be described in a wide range of invertebrates [6-8], and generate new questions on their biology, ecology, epidemiology, geographical distribution and potential pathogenicity.

\footnotetext{
*Correspondence: laura.tomassone@unito.it

${ }^{1}$ Department of Veterinary Sciences, University of Turin, Largo Braccini 2,

10095 Grugliasco (Torino), Italy

Full list of author information is available at the end of the article
}

In this paper, we revised the neglected aspects of the biology of tick-transmitted Rickettsia spp., their relationship with tick vectors and vertebrate hosts, and the challenges of rickettsial research in a changing environment.

\section{Natural foci of rickettsiae and tick vectors}

The genus Rickettsia comprises intracellular endosymbionts with remarkably adaptive potential. It is approximately 150 million years old, and splits into two main clades, one primarily infecting arthropods, and the second infecting a variety of other eukaryotes, such as protists and leeches [7]. Around 24\% of terrestrial arthropod species are thought to be infected with Rickettsia endosymbionts [8].

The best-known members of this bacterial genus are human pathogens associated with blood-feeding arthropods. Humans are accidental hosts, except for Rickettsia prowa$z e k i i$, for which they are reservoir [9]. Reconstructed phylogeny of the genus Rickettsia, based on whole genome sequence data, showed that hard ticks (Ixodidae) are found across phylogeny, which correlates with the fact that they are ancestral arthropod hosts for rickettsiae [10]. Most tick-borne rickettsiae belong to the spotted fever group (SFG). They are maintained in nature by transstadial and transovarial transmission in ticks [11], so it is generally stated that ticks act both as vector and as reservoir of most SFG species [12]. Rickettsia-free ticks may acquire the bacteria by feeding on rickettsemic host, cofeeding or sexual transmission [13-15]. 
Looking at the associations with tick genera [1,2], it is evident that the level of host specificity varies among rickettsial species. Some of them seem to be strictly linked with one tick vector, such as $R$. conorii with $R h i$ picephalus sanguineus (s.l.) ticks (with the exception of $R$. conorii caspia transmitted by Rh. pumilio in the Caspian Sea region), and Rickettsia sp. 364D with Dermacentor occidentalis [2]. Other rickettsiae are related to tick species belonging to the same genus, such as Rickettsia slovaca, which infects the two Dermacentor species present in Europe, D. marginatus and D. reticulatus $[11,16]$. Finally, $R$. rickettsii is an example of a Rickettsia associated with a broad spectrum of tick species belonging to different genera [2].

Most Rickettsia species are transmitted by hard ticks, but rickettsiae in soft ticks (Argasidae) are continuously being identified (Table 1). Even though there are no reports of human cases due to soft-ticks bites so far, the ability of argasid ticks to transmit rickettsiae to vertebrates and the possible implications to human and animal health are worth further study. In fact, among the identified rickettsiae, some are pathogenic (i.e. $R$. felis). Moreover, among the soft tick species infected by rickettsiae, some commonly feed on humans, such as Carios capensis, Ornithodoros erraticus and $O$. moubata; in particular, the latter two tick species are already recognized vectors of tick-borne relapsing fever borreliae to humans [17].

Rickettsiae can have deleterious effects on their invertebrate hosts; for example, they have been shown to determine parthenogenesis in Hymenoptera, male killing in Coleoptera or larger body size in leeches (Hirudinida) $[6,18]$. For ixodid ticks, negative effects can occur on their viability and survival, on the oviposition and percentage of successful transovarial transmission within each arthropod generation. These effects have been observed in ticks infected in the laboratory with different rickettsiae [11, 19-22], and are more evident when pathogenic species [2] infect ticks (e.g. $R$. rickettsii and R. conorii), compared to less (e.g. Rickettsia sp. strain Atlantic rainforest) or non-pathogenic species (e.g. R. montanensis, $R$. bellii and $R$. rhipicephalii). Interestingly, external factors, such as temperature, can influence these phenomena. For instance, $R$ h. sanguineus (s.l.) can maintain $R$. conorii conorii for several generations, but naturally infected specimens showed higher mortality, compared to uninfected ticks, when exposed to low temperatures $\left(4{ }^{\circ} \mathrm{C}\right)$, so that winter colds may explain the low prevalence of $R$. conorii-positive ticks in nature [23]. Conversely, $D$. andersoni ticks survived better to experimental $R$. rickettsii infection when incubated at $4{ }^{\circ} \mathrm{C}$ [19]. The loss of performance in ticks induced by

Table 1 Rickettsia species associated with soft ticks

\begin{tabular}{|c|c|c|c|c|c|}
\hline Rickettsia species $^{a}$ & Methodology (detected/isolated) & Tick species & Animal or site association & Geographical origin & Reference \\
\hline R. bellii & Detected & Carios capensis & Seabirds & Western Indian Ocean Islands & [91] \\
\hline R. felis & Detected & Carios capensis & Brown pelican nests & USA & [92] \\
\hline \multirow[t]{5}{*}{ R. hoogstraalii } & Detected & Argas persicus & Human dwellings, trees & Ethiopia & [93] \\
\hline & Detected & Carios capensis & Seabirds & Japan & [94] \\
\hline & Isolated & Carios capensis & ns & USA & [95] \\
\hline & Detected & Carios capensis & Seabirds & Western Indian Ocean Islands & [91] \\
\hline & Detected & Carios sawaii & Seabirds & Japan & [94] \\
\hline \multirow[t]{2}{*}{ R. lusitaniae } & Isolated & Ornithodoros erraticus & Pigs/pigpens & Portugal & [96] \\
\hline & Detected & Ornithodoros yumatensis & Bat caves & Mexico & [97] \\
\hline R. nicoyana & Isolated & Ornithodoros knoxjonesi & Balantiopteryx plicata & Costa Rica & [98] \\
\hline R. wissemanii & Detected & Ornithodoros hasei & Bats & French Guiana & [99] \\
\hline R. argasii & Isolated & Argas dewae & Bats boxes & Australia & [2] \\
\hline \multirow[t]{7}{*}{ Rickettsia spp. } & Isolated & Argas persicus & ns & Armenia & {$[100]$} \\
\hline & Detected & Argas vespertilionis & Bat-infested building & France & [101] \\
\hline & Detected & Carios capensis & Yellow-legged gull nests & Algeria & [102] \\
\hline & Detected & Carios kelleyi & Bat-infested building & USA & [103] \\
\hline & Detected & Ornithodoros erraticus & Rodent burrows & Algeria & [102] \\
\hline & Detected & Ornithodoros moubata & Human dwellings & Tanzania & [104] \\
\hline & Detected & Ornithodoros rupestris & Rodent burrows & Algeria & [102] \\
\hline
\end{tabular}


rickettsial infections, and interactions with environmental factors, are still poorly understood.

Recent studies have also addressed the positive influence of rickettsial endosymbionts on tick hosts. For example, metabolic reconstructions of rickettsial genomes in Ixodes scapularis and I. pacificus ticks showed that all genes required for folic acid biosynthesis are present in rickettsial genomes [24]. Later, it was proven that Rickettsia species phylotype GO21 of I. pacificus produces an enzyme involved in the vitamin B9 biosynthesis, which indicates nutritional interactions between this endosymbiont and its host [25].

Other studies revealed that rickettsial endosymbionts have negative effects on pathogenic rickettsiae within the tick vector and preclude their secondary infection, through a rickettsial interference in ovarian tissue colonization, or transovarial transmission [19, 26, 27]. For instance, this interference was observed between $R$. peacockii and $R$. rickettsii [28], R. rhipicephali and $R$. montana [26] and, more recently, between rickettsial species in different families, i.e. between $R$. bellii and $A$. marginale in D. andersoni ticks [29]. Therefore, Rickettsia endosymbionts are thought to protect ticks against tick-borne pathogens colonization, and to condition their abundance and diversity [30]. However, positive interactions with pathogens can also occur, as was shown between Rickettsia spp. and Borrelia lusitaniae in lizards' ticks [31]. The simultaneous occurrence of multiple pathogens in ticks is a topic of concern, since their concurrent transmission to vertebrate hosts can have severe health consequences for patients [32].

The study of the interactions of endosymbionts with ticks and with pathogens within ticks, and among different pathogens, is still on its infancy but has a promising future. Moreover, it has the very fascinating perspective of using tick microbiome manipulation to limit the transmission and maintenance of pathogens in ticks, thus decreasing their vectorial competence $[29,30]$. However, the unavailability of a suitable axenic medium for rickettsiae culture hampers many conventional genetic approaches. Recent identification of 51 host metabolites required by Rickettsia, which offered information about host-dependent metabolism, may help dissociating rickettsiae from eukaryotic cells [33].

\section{Rickettsia spp. infection in animals}

As previously said, ticks are usually thought to be the main reservoir of SFG rickettsiae thanks to transstadial and transovarial transmission. However, studies have demonstrated the occurrence of transovarial transmission in only a limited number of species [11]. Moreover, the efficiency of vertical transmission varies according to the rickettsial and tick species [19, 34], and transmission may not occur in female ticks infected by sexual/co- feeding transmission [35]. Vertebrate hosts may thus be necessary to maintain and perpetuate some rickettsial agents in nature [36]. However, systemic transmission of infection from the vertebrate host to feeding ticks seems to have a limited importance, because rickettsemia in most vertebrates occurs at low level and/or it is transient [37]. In fact, few studies provide evidence that animal species are competent reservoirs of Rickettsia spp. Generally, we consider as 'reservoir' a host that permanently maintains a pathogen and is able to transmit it to the target population/vector [38]. To determine potential reservoirs, studies identifying natural infection in hosts (through antibody detection, isolation of the infectious agent, or its genes from the host) may be useful, together with xenodiagnostic experiments, to show the host susceptibility to the infection and its ability to transmit the pathogen to the vector. In the case of Rickettsia spp., natural infection has been demonstrated in a number of vertebrate species, but the studies rarely investigated the persistence of the agent in the host. In regards to xenodiagnostic experiments, most of them have shown that only a small percentage of uninfected feeding ticks were able to acquire the infection from the rickettsemic host (Table 2).

The dog was identified as reservoir of $R$. conorii by means of experimental studies. In fact, dogs infected both by inoculation and by using infected ticks were able to infect feeding Rh. sanguineus (s.l.) larvae and nymphs [39]. In turn, these ticks were able to transmit the rickettsiae to the next developmental stages and to naïve dogs. Dogs maintained the ability to transmit the infection to ticks for at least one month post-infection, also when rickettsemia was not detectable by PCR. They developed antibodies within two weeks after the infection, which declined within three to six months, and their persistence and titres were shown to be dose dependent [39].

Rickettsial transmission to feeding ticks was also demonstrated, in the Americas, in opossums, lagomorphs, capybaras, small rodents ( $R$. rickettsii) [40-44] and goats (North American isolate of $R$. slovaca) [45]. In Europe, Heylen et al. [46] showed that experimentally infected great tits (Parus major) transmit $R$. helvetica to feeding I. ricinus and facilitate co-feeding.

Co-feeding is in fact a transmission mechanism, which may be very important in perpetuating rickettsiae in nature $[20,47]$. It can occur among both infected and uninfected ticks simultaneously feeding in close proximity on the host's skin, and by 'extended co-feeding transmission' in a localized site, after the infected ticks have dropped off [48]. Local skin infection may facilitate the transmission, thanks to the tropism of SFG rickettsiae for the endothelial cells of peripheral blood vessels [49]. As an example, natural transmission of $R$. conorii 
Table 2 Natural and experimental infections by tick-borne Rickettsia spp. in vertebrate host species

\begin{tabular}{|c|c|c|c|c|}
\hline $\begin{array}{l}\text { Rickettsia } \\
\text { species }\end{array}$ & Host species & $\begin{array}{l}\text { Type of } \\
\text { infection }\end{array}$ & Methodology demonstrating the infection & Reference \\
\hline \multirow[t]{11}{*}{ R. rickettsii } & Birds (Ciconiiformes, Piciformes, Passeriformes) & Natural & Antibodies & {$[41]$} \\
\hline & Capybara (Hydrochoerus hydrochaeris) & Experimental & $\begin{array}{l}\text { Rickettsemia, infection transmitted to } \\
\text { Amblyomma cajennense ticks (25-30\% } \\
\text { success) }\end{array}$ & {$[44]$} \\
\hline & \multirow[t]{2}{*}{ Rodents and lagomorphs } & Natural & Isolation & {$[41,105]$} \\
\hline & & Experimental & $\begin{array}{l}\text { Rickettsemia, infection transmitted to } \\
\text { Dermacentor andersoni ticks }\end{array}$ & {$[40,42]$} \\
\hline & \multirow[t]{2}{*}{ Opossum (Didelphis spp.) } & Natural & Isolation & $\begin{array}{l}{[41,106,} \\
107]\end{array}$ \\
\hline & & Experimental & $\begin{array}{l}\text { Rickettsemia, infection transmitted to } \\
\text { Amblyomma cajennense ticks ( } 5 \% \text { success) }\end{array}$ & {$[41,43]$} \\
\hline & White-tailed deer (Odocoileus virginianus) & Natural & Antibodies & [41] \\
\hline & Wild carnivores (fox, raccoon, skunk) & Natural & Antibodies & {$[41]$} \\
\hline & \multirow[t]{2}{*}{ Dog (Canis lupus familiaris) } & Experimental & Antibodies & {$\left[52^{\mathrm{a}}\right]$} \\
\hline & & Natural & Antibodies, DNA in blood & $\begin{array}{l}{\left[53^{\mathrm{a}}, 59,\right.} \\
60]\end{array}$ \\
\hline & Horse (Equus caballus) & Experimental & Antibodies & [108] \\
\hline \multirow[t]{2}{*}{ R. parkeri } & Opossum (Didelphis spp.) & Experimental & DNA in blood & [109] \\
\hline & Dog (Canis lupus familiaris) & Natural & Antibodies, DNA in blood & {$[110,111]$} \\
\hline \multirow[t]{4}{*}{ R. conorii } & Lagomorphs (Oryctolagus cuniculus, Lepus granatensis) & Natural & Antibodies & {$[112,113]$} \\
\hline & Cat (Felis catus) & Natural & Antibodies & {$[114]$} \\
\hline & \multirow[t]{2}{*}{ Dog (Canis lupus familiaris) } & Experimental & $\begin{array}{l}\text { Antibodies, infection transmitted to } R h \text {. } \\
\text { sanguineus ticks }\end{array}$ & [39] \\
\hline & & Natural & Antibodies, DNA in blood & $\begin{array}{l}{\left[54-56^{\mathrm{a}},\right.} \\
58]\end{array}$ \\
\hline $\begin{array}{l}\text { R. conorii- } \\
\text { like }\end{array}$ & Bats (African species) & Natural & DNA in blood & {$[115]$} \\
\hline \multirow[t]{8}{*}{ R. helvetica } & Deer (Cervus nippon, Capreolus capreolus) & Natural & DNA in blood & {$[116,117]$} \\
\hline & \multirow[t]{2}{*}{$\begin{array}{l}\text { Passerine birds (Erithacus rubecula, Parus major, Prunella } \\
\text { modularis) }\end{array}$} & $\begin{array}{l}\text { Experimental (in } \\
\text { Parus major) }\end{array}$ & Infection transmitted to Ixodes ricinus ticks & [46] \\
\hline & & Natural & DNA in blood & [118] \\
\hline & Hedgehog (Erinaceus europaeus) & Natural & DNA in tissues & [119] \\
\hline & Lizard (Teira dugesii, Podarcis muralis) & Natural & DNA in tissues & {$[120,121]$} \\
\hline & $\begin{array}{l}\text { Small rodents (Myodes glareolus, Microtus arvalis, M. arvestis, } \\
\text { Apodemus flavicollis, A. sylvaticus, Mus musculus) }\end{array}$ & Natural & Antibodies, DNA in tissues & $\begin{array}{l}{[117} \\
122-124]\end{array}$ \\
\hline & Wild boar (Sus scrofa) & Natural & DNA in blood & {$[117]$} \\
\hline & Dog (Canis lupus familiaris) & Natural & Antibodies & [61] \\
\hline R. massiliae & Cat (Felis catus) & Natural & Antibodies & {$[114]$} \\
\hline \multirow{2}{*}{$\begin{array}{l}R \text {. } \\
\text { monacensis }\end{array}$} & Lizard (Teira dugesii) & Natural & DNA in tissues & [120] \\
\hline & Dog (Canis lupus familiaris) & Natural & DNA in blood & {$[125]$} \\
\hline R. raoultii & Dog (Canis lupus familiaris) & Natural & Antibodies, DNA in blood & {$[61,126]$} \\
\hline \multirow[t]{6}{*}{ R. slovaca } & \multirow[t]{2}{*}{ Small rodents (Apodemus spp., Myodes glareolus) } & Natural & DNA in tissues & [50] \\
\hline & & Experimental & Antibodies & {$[127]$} \\
\hline & Wild boar (Sus scrofa) & Natural & DNA in tissues & [128-130] \\
\hline & Cattle (Bos taurus) & Natural & Antibodies & {$[131]$} \\
\hline & Dog (Canis lupus familiaris) & Natural & Antibodies & {$[61]$} \\
\hline & Goat (Capra hircus) & Natural & Antibodies & [131] \\
\hline
\end{tabular}


Table 2 Natural and experimental infections by tick-borne Rickettsia spp. in vertebrate host species (Continued)

\begin{tabular}{lllll}
\hline $\begin{array}{l}\text { Rickettsia } \\
\text { species }\end{array}$ & Host species & $\begin{array}{l}\text { Type of } \\
\text { infection }\end{array}$ & Methodology demonstrating the infection & Reference \\
\hline & & $\begin{array}{l}\text { Experimental } \\
\text { (American strain) }\end{array}$ & $\begin{array}{l}\text { DNA in tissues, infection transmitted to } \\
\text { Dermacentor variabilis ticks (< 5\% success) }\end{array}$ & {$\left[45^{\text {a }}\right]$} \\
& Sheep (Ovis aries) & Natural & Antibodies & [131] \\
\hline
\end{tabular}

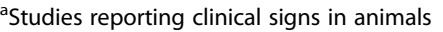

israelensis was shown among Rh. sanguineus (s.l.) ticks co-feeding on dogs. The transmission was less efficient when co-feeding occurred on seropositive dogs [47], but Levin et al. [49] observed that it might remain efficient at high densities of co-feeding ticks. Therefore, high tick aggregation levels on the same individuals can favour Rickettsia maintenance in the tick populations. Recent studies suggest the occurrence in nature of this nonsystemic transmission, in animals that are preferred hosts for the immature stages of tick vectors (e.g. small mammals, passerine birds), especially in heavily infested individuals $[46,50]$. In this sense, vertebrates act as 'amplifiers' of rickettsiae, contributing to its spread in the ecosystem, even in the absence of a systemic infection. However, Paddock et al. [51] recently suggested that ticks could acquire SFG rickettsiae from ear tissues of systemically infected hosts; in fact, they observed rickettsial aggregates, persisting for at least 14 days, in the ear dermis of guinea pigs inoculated intraperitoneally with Rickettsia sp. Black Gap. Therefore, we need further research to clarify the relative importance of systemic and non-systemic transmission mechanisms for the maintenance of Rickettsia spp.

In general, clinical illness is not reported in animals infected by tick-borne rickettsiae. Cases of illness have occurred in dogs infected by $R$. rickettsii $[52,53]$ and $R$. conorii [54-56] in endemic areas. Clinical signs were similar to humans', including fever, lethargy, anorexia, depression, cutaneous petechiae and ecchymoses, epistaxis, conjunctivitis, ocular discharge, lymph node enlargement, diarrhoea, weight loss and dehydration. Haematological abnormalities included anaemia, thrombocytopenia and leucocytosis. In the case of $R$. conorii, symptoms are generally mild and of short duration, so that the disease goes unnoticed [39]. In any case, the clinical diagnosis in dogs is challenging, since other pathogens can cause similar clinical signs, such as Ehrlichia canis, Anaplasma platys, Babesia canis and Hepatozoon canis [55]. Studies from distinct geographical regions showed the presence of antibodies and DNA of other Rickettsia species in dogs' blood (Table 2). Some of these rickettsiae are pathogenic to humans (e.g. $R$. helvetica, $R$. slovaca, $R$. parkeri and $R$. raoultii), but all observed animals were asymptomatic.

Actually, the mechanisms determining the different pathogenicity and virulence of rickettsial species are poorly understood, even in humans [57]. Future research on the interactions between SFG rickettsiae and the host intracellular environment could help in understanding why most animals do not show any clinical sign when infected by rickettsiae that are pathogenic to humans. In addition, histologic studies in mammals would be valuable, in order to characterize specific features related to Rickettsia spp. infections (e.g. changes in tissues due to vasculitis).

Finally, it is important to remember that animals serve as sentinels for rickettsial circulation and are useful for rickettsiosis surveillance in humans. For example, natural antibodies to SFG rickettsiae were detected in dogs living in close proximity to human cases of Mediterranean spotted fever [58], and Rocky Mountain spotted fever $[59,60]$. Dogs seropositive to $R$. helvetica, $R$. raoultii and $R$. slovaca were reported in Austria [61], indicating a contact with SFG species prevalent in continental Europe. Generally, high prevalence of rickettsial infection in ticks parasitizing dogs correlates with high levels of SFG rickettsiae antibodies in dogs $[55,56,62,63]$.

\section{New Rickettsiae}

During the last decades, molecular techniques have allowed researchers to genetically characterize several bacteria within the genus Rickettsia before they have been cultured. According to taxonomic criteria proposed by experts, these uncultured rickettsiae can be given Candidatus $(\mathrm{Ca}$.) status and are considered potential new species of Rickettsia [64].

In regards to Rickettsia culture, 'temperature' and 'enrichment of medium' variables seem to be essential to establish a pure culture. Different cell lines, media with supplementations and culture conditions have been tested for the in vitro growth of Rickettsia spp. [65]. Nevertheless, the isolation of these bacteria is still a challenge that not always succeeds. Thus, several genotypes of Rickettsia were observed in DEBONEL/TIBOLA patients, which were different from validated Rickettsia species involved as human pathogens [66]. One of them is Rickettsia rioja, which has been molecularly characterised and detected from human blood and biopsies, and ticks, but to date remains uncultured [67, 68].

The number of microorganisms that fulfil criteria of "Ca. Rickettsia" spp. continues to increase in Europe and in other continents (Tables 3 and 4). If the analyses of 
Table 3 "Candidatus Rickettsia" spp. in Europe

\begin{tabular}{|c|c|c|c|c|c|}
\hline $\begin{array}{l}\text { "Ca. Rickettsia" } \\
\text { spp. }\end{array}$ & $\begin{array}{l}\text { Associated arthropod or } \\
\text { source }\end{array}$ & $\begin{array}{l}\text { Country of the first } \\
\text { identification }\end{array}$ & Reference & $\begin{array}{l}\text { Associated human } \\
\text { disease }\end{array}$ & $\begin{array}{l}\text { Reference of associated } \\
\text { disease }\end{array}$ \\
\hline $\begin{array}{l}\text { "Ca. R. } \\
\text { tarasevichiae" }\end{array}$ & Ixodes persulcatus & Russia & [132] & $\begin{array}{l}\text { "Ca. R.tarasevichiae" } \\
\text { infection }\end{array}$ & [133] \\
\hline "Ca. R. kotlanii" & Ixodes spp. & Hungary & [134] & - & - \\
\hline "Ca. R. barbariae" & Rhipicephalus turanicus & Italy & [135] & - & - \\
\hline "Ca. R. rioja" & Dermacentor marginatus & Spain & {$[67]$} & DEBONEL/TIBOLA & {$[68]$} \\
\hline "Ca. R. siciliensis" & Rhipicephalus turanicus & Italy & [136] & - & - \\
\hline "Ca. R. uralica" & Ixodes trianguliceps & Russia & [137] & - & - \\
\hline "Ca. R. mendelii" & Ixodes ricinus & Czech Republic & [138] & - & - \\
\hline
\end{tabular}

additional rickettsial genes are needed to define the taxonomic status of a novel rickettsial organism, it must be designated as a strain. This was, for instance, the case of Rickettsia sp. strain Davousti. It was first detected in Amblyomma tholloni from African elephants in 2007 [69], and further genetically characterized as " $\mathrm{Ca}$. Rickettsia davousti" from one Amblyomma nymph attached to a traveller from Gabon to Spain in 2015 [70]. Table 5 details the new strains of Rickettsia.

The association of a bacterium with human disease can be found even 65 years after its discovery, as happened with Rickettsia parkeri [71]. Therefore, all Rickettsia organisms (species, Ca. or strains) must be considered as potential human pathogens.

Table 4 "Candidatus Rickettsia" spp. outside Europe

\begin{tabular}{|c|c|c|c|c|c|}
\hline "Ca. Rickettsia" spp. & Associated arthropod or source & $\begin{array}{l}\text { Country of the first } \\
\text { identification }\end{array}$ & $\begin{array}{l}\text { Reference of the } \\
\text { first identification }\end{array}$ & $\begin{array}{l}\text { Associated } \\
\text { human } \\
\text { disease }\end{array}$ & $\begin{array}{l}\text { Reference of } \\
\text { associated } \\
\text { disease }\end{array}$ \\
\hline "Ca. R. andeanae" & Amblyomma maculatum, Ixodes boliviensis & Perú & [139] & - & - \\
\hline "Ca. R. kellyi" & $\begin{array}{l}\text { Unknown arthropod (detected in a human skin } \\
\text { biopsy from a maculopapular lesion) }\end{array}$ & India & {$[140]$} & Unnamed & [140] \\
\hline "Ca. R. principis" & Haemaphysalis japonica & Russia & [141] & - & - \\
\hline $\begin{array}{l}\text { "Ca. R. } \\
\text { tasmanensis" }\end{array}$ & Ixodes tasmani & Australia & [142] & - & - \\
\hline $\begin{array}{l}\text { "Ca. Rickettsia" sp. } \\
\text { strain Argentina }\end{array}$ & $\begin{array}{l}\text { Amblyomma parvum, Amblyomma } \\
\text { pseudoconcolor }\end{array}$ & Argentina & [143] & - & - \\
\hline "Ca. R. cooleyi" & Ixodes scapularis & USA & {$[144]$} & - & - \\
\hline "Ca. R. hebeiii" & Haemaphysalis longicornis & China & {$[145]$} & - & - \\
\hline "Ca. R. liberiensis" & Ixodes muniensis & Liberia & {$[146]$} & - & - \\
\hline "Ca. R. kulagini" & Rhipicephalus annulatus & Kenya & [147] & - & - \\
\hline "Ca. R. angustus" & Ixodes angustus & Canada & {$[148]$} & - & - \\
\hline "Ca. R. kingi" & Ixodes kingi & Canada & [149] & - & - \\
\hline $\begin{array}{l}\text { "Ca. R. } \\
\text { senegalensis" }\end{array}$ & Ctenocephalides felis (cat flea) & Senegal & {$[150]$} & - & - \\
\hline "Ca. R. davousti" & Amblyomma sp. (attached to a human) & Gabon & [70] & - & - \\
\hline $\begin{array}{l}\text { "Ca. R. } \\
\text { sepangensis" }\end{array}$ & Amblyomma varanense & Malaysia & [151] & - & - \\
\hline "Ca. R. johorensis" & Amblyomma helvolum, Amblyomma varanense & Malaysia & [151] & - & - \\
\hline $\begin{array}{l}\text { "Ca. R. } \\
\text { goldwasserii" }\end{array}$ & Haemaphysalis spp., Rhipicephalus spp. & Palestine & {$[152]$} & - & - \\
\hline "Ca. R. gannanii" & Haemaphysalis qinghaiensis & China & [153] & - & - \\
\hline "Ca. R. indica" & Human blood & $\begin{array}{l}\text { Imported from India } \\
\text { to Japan (traveler) }\end{array}$ & {$[154]$} & Unnamed & [154] \\
\hline "Ca. R. moyalensis" & Rhipicephalus appendiculatus & Kenya & {$[155]$} & - & - \\
\hline "Ca. R. wissemanii" & Ornithodoros hasei (soft tick) & French Guiana & {$[100]$} & - & - \\
\hline
\end{tabular}


Table 5 Strains of Rickettsia spp. (without Candidatus status)

\begin{tabular}{|c|c|c|c|c|c|}
\hline Rickettsia sp. strain & $\begin{array}{l}\text { Associated arthropod or } \\
\text { source }\end{array}$ & $\begin{array}{l}\text { Country of the first } \\
\text { identification }\end{array}$ & $\begin{array}{l}\text { Reference of the first } \\
\text { identification }\end{array}$ & $\begin{array}{l}\text { Associated human } \\
\text { disease }\end{array}$ & $\begin{array}{l}\text { Reference of } \\
\text { associated disease }\end{array}$ \\
\hline $\begin{array}{l}\text { Rickettsia sp. strain } \\
\text { Uilenbergi }\end{array}$ & Amblyomma tholloni & Central African Republic & [69] & - & - \\
\hline $\begin{array}{l}\text { Rickettsia sp. Atlantic } \\
\text { rain forest }\end{array}$ & $\begin{array}{l}\text { Amblyomma ovale } \\
\text { Rhipicephalus sanguineus }\end{array}$ & Brazil & [156] & Unnamed & [157] \\
\hline $\begin{array}{l}\text { Rickettsia sp. strain } \\
\text { Pampulha }\end{array}$ & Amblyomma dubitatum & Brazil & {$[158]$} & - & - \\
\hline $\begin{array}{l}\text { Rickettsia sp. strain } \\
\text { colombianensi }\end{array}$ & Amblyomma dissimile & Colombia & [159] & - & - \\
\hline $\begin{array}{l}\text { Rickettsia sp.- novel } \\
\text { isolate }\end{array}$ & Ixodes ricinus & Czech Republic & [160] & - & - \\
\hline $\begin{array}{l}\text { Rickettsia sp. strain } \\
\text { Tselenti }\end{array}$ & $\begin{array}{l}\text { Hyalomma anatolicum } \\
\text { excavatum } \\
\text { Rhipicephalus turanicus }\end{array}$ & Cyprus & [161] & - & - \\
\hline $\begin{array}{l}\text { Rickettsia sp. strain IbR/ } \\
\text { CRC }\end{array}$ & Ixodes boliviensis & Costa Rica & [162] & - & - \\
\hline
\end{tabular}

In a near future, exploring the bacteriome of arthropods (ticks, fleas, mosquitoes and others) will mean a step forward for the knowledge of potential new Rickettsia species and for the improvement of diagnosis and treatment of vector-borne diseases [72].

\section{Rickettsioses in a changing environment}

Due to the close relationship between ticks and vectors, changes in the distribution of arthropods are very important for the epidemiology of rickettsiosis. Climate, density of vertebrate hosts, landscape features and anthropogenic factors are the drivers of such changes [73]. While these may affect in a relative way rickettsial agents with widespread distribution of vectors (e.g. the fleatransmitted $R$. typhi and $R$. felis, or R. prowazekii, transmitted by the body louse), they can have greater importance for tick-borne rickettsioses, most of which are restricted to specific endemic areas. For instance, D. reticulatus colonization of new areas in Eastern Europe was associated to cases of DEBONEL/TIBOLA in the human population [74]. In the case of I. ricinus, its geographical expansion [73] has not been accompanied so far with an increase of human cases of associated rickettsioses (caused by $R$. helvetica and $R$. monacensis). This could be due to a low competence of I. ricinus as a vector of these Rickettsia species and/or to their low pathogenicity [75].

As regards climate changes, it is known that, for example, warming has an impact on the activity and aggressiveness of the brown $\operatorname{dog}$ tick Rh. sanguineus (s.l.), increasing human attacks and the possibility of transmission of severe rickettsioses [76].

The availability of vertebrate animals that are common tick hosts may favour the maintenance and transmission of Rickettsia spp. The introduction of wild animals in urban areas may facilitate interchange of arthropods with domestic animals, increasing human exposure to
Rickettsia spp. [77]. Vice versa, pathogens infecting domestic animals may threaten the health of wild animals when they share the same habitat (e.g. livestock and Andean tapirs in South America) [78]. Moreover, birds are possible dispersers of Rickettsia spp. and other tickborne pathogens $[79,80]$. It is known that migratory birds respond to environmental changes and are able to adjust their timing of migration according to climate. This can affect the life-cycle of ticks feeding on them and, consequently, the potential transmission pattern of tick-borne pathogens.

Social changes (e.g. demographics, availability of public health care infrastructures, human behaviour, trade and travel, economic development, war and famine) may also have an impact on vector dynamics and alter pathogen adaptation or evolution. Regarding human behaviour, outdoor activities have increased in the last decades by leisure or due to the economic crisis (e.g. picking mushrooms for trade), accompanied by the risk of being bitten by ticks [81].

International trade and travel are likely routes of introduction of rickettsiosis. In fact, travel-acquired rickettsioses are frequently considered imported diseases. Several travel-associated infections refer to tourists infected by $R$. africae in sub-Saharan Africa, who develop African tick-bite fever (ATBF) [82]. It has been suspected that tick-borne infections can also affect individuals who have recently been visited by travellers, as was the case of the first DEBONEL/TIBOLA related to a $D$. marginatus bite in a patient without travel history documented in United Kingdom, where this tick species had not been notified yet [83].

\section{Conclusions}

We live in a changing world and we will probably have to face threats to health more and more frequently. The 
recent finding of the tick-borne encephalitis (TBE) virus in ticks and roe deer from a forested area in the Netherlands [84] led to the identification of the two first autochthonous cases of TBE in this country [85, 86]. Similarly, the description of the two first cases of Crimean-Congo haemorrhagic fever (CCHF) in Spain in 2016 [87], followed the identification of the etiologic agent (CCHF virus) in ticks from southern Europe several years before [88]. Could we also expect the emergence of tick-borne rickettsioses? Indeed, we do not know the actual impact of rickettsial diseases in Europe. The main sources of information we have are published papers, but often only impact reports are available to the scientific community, while other relevant data are less accessible (e.g. grey literature). In addition, official information is not consistently updated; for example, the last technical report on tick-borne rickettsioses from the 'European Centre for Disease Prevention and Control' (ECDC) dates back to October 2013 and includes data up to 2010 [89]. In order to tackle emerging threats in a more timely and effective way, a major effort is required in Europe to harmonize data collection and notification on rickettsioses (and other tick-borne diseases). Furthermore, surveillance could be strengthened by sharing of information and inter-disciplinary collaboration among public, animal and environmental health, based on a 'One Health' approach [90].

\section{Acknowledgements}

This article has been prepared under the networking of WG5 of the COST Action TD1303, EurNegVec - the European Network for Neglected Vectors and Vector-Borne Infections. We thank the two anonymous reviewers for their insightful comments and suggestions.

\section{Authors' contributions}

All authors designed and wrote the manuscript. All authors read and approved the final manuscript.

Ethics approval and consent to participate

Not applicable.

\section{Competing interests}

The authors declare that they have no competing interests.

\section{Publisher's Note}

Springer Nature remains neutral with regard to jurisdictional claims in published maps and institutional affiliations.

\footnotetext{
Author details

'Department of Veterinary Sciences, University of Turin, Largo Braccini 2, 10095 Grugliasco (Torino), Italy. ${ }^{2}$ Center of Rickettsiosis and Arthropod-Borne Diseases, Hospital San Pedro-CIBIR, C/ Piqueras 98, 26006 Logroño, Spain. ${ }^{3}$ Department of Biology, Faculty of Medicine, Masaryk University, Kamenice 5, 62500 Brno, Czech Republic. ${ }^{4}$ Department of Biology and Wildlife Diseases, Faculty of Veterinary Hygiene and Ecology, University of Veterinary and Pharmaceutical Sciences Brno, Palackého 1946/1, 61242 Brno, Czech Republic. ${ }^{5}$ National Institute of Health Dr. Ricardo Jorge, Av. da Liberdade 5, 2965-575 Aguas de Moura, Portugal.
}

Received: 9 November 2017 Accepted: 18 April 2018

Published online: 24 April 2018

\section{References}

1. Raoult D, Roux V. Rickettsioses as paradigms of new or emerging infectious diseases. Clin Microbiol Rev. 1997;10:694-719.

2. Parola P, Paddock CD, Socolovschi C, Labruna MB, Mediannikov O, Kernif T, et al. Update on tick-borne rickettsioses around the world: a geographic approach. Clin Microbiol Rev. 2013;26:657-702.

3. Maxey EE. Some observations of the so-called spotted fever of Idaho. Med Sentinel. 1899;10:433-8.

4. Ricketts HT. Some aspects of Rocky Mountain spotted fever as shown by recent investigations. Med Rec. 1909;76:843-5.

5. Walker DH, Fishbein DB. Epidemiology of rickettsial diseases. Eur J Epidemiol. 1991;7:237-45.

6. Noda H, Munderloh UG, Kurtti TJ. Endosymbionts of ticks and their relationship to Wolbachia spp. and tick-borne pathogens of humans and animals. Appl Environ Microbiol. 1997;63:3926-32.

7. Weinert LA, Werren JH, Aebi A, Stone GN, Jiggins FM. Evolution and diversity of Rickettsia bacteria. BMC Biol. 2009;7:6

8. Weinert LA, Araujo-Jnr EV, Ahmed MZ, Welch JJ. The incidence of bacterial endosymbionts in terrestrial arthropods. Proc Biol Sci. 2015;282:20150249.

9. Olano JP. Rickettsial infections. Ann N Y Acad Sci. 2005;1063:187-96.

10. Murray GGR, Weinert LA, Rhule EL, Welch JJ. The phylogeny of Rickettsia using different evolutionary signatures. How tree-like is bacterial evolution? Syst Biol. 2016:65:265-79.

11. Socolovschi C, Mediannikov O, Raoult D, Parola P. The relationship between spotted fever group Rickettsiae and ixodid ticks. Vet Res. 2009;40:34.

12. Řeháček J. Ecological relationships between ticks and rickettsiae. Eur J Epidemiol. 1989:5:407-13.

13. Philip CB. Some epidemiological considerations in Rocky Mountain spotted fever. Public Health Rep. 1959;74:595-600.

14. Hayes SF, Burgdorfer W, Aeschlimann A. Sexual transmission of spotted fever group rickettsiae by infected male ticks detection of rickettsiae in immature spermatozoa of Ixodes ricinus. Infect Immun. 1980;27:638-42.

15. McDade JE, Newhouse VF. Natural history of Rickettsia rickettsii. Annu Rev Microbiol. 1986:40:287-309.

16. Řeháček J. Rickettsia slovaca, the organism and its ecology. Acta SC Nat Brno. 1984;18:1-50.

17. Estrada-Peña A, Jongejan F. Ticks feeding on humans a review of records on human-biting Ixodoidea with special reference to pathogen transmission. Exp Appl Acarol. 1999;23:685-715.

18. Perlman SJ, Hunter MS, Zchori-Fein E. The emerging diversity of Rickettsia. Proc Biol Sci. 2006:273:2097-106.

19. Niebylski ML, Peacock MG, Schwan TG. Lethal effect of Rickettsia rickettsii on its tick vector (Dermacentor andersoni). Appl Environ Microbiol. 1999;65:773-8.

20. Levin ML, Killmaster LF, Zemtsova GE, Grant D, Mumcuoglu KY, Eremeeva $\mathrm{ME}$, et al. Incongruent effects of two isolates of Rickettsia conorii on the survival of Rhipicephalus sanquineus ticks. Exp Appl Acarol. 2009:49:347-59.

21. Labruna MB, Ogrzewalska M, Soares JF, Martins TF, Soares HS, Moraes-Filho $J$, et al. Experimental infection of Amblyomma aureolatum ticks with Rickettsia rickettsii. Emerg Infect Dis. 2011;17:829-34.

22. Krawczak FS, Agostinho WC, Polo G, Moraes-Filho J, Labruna MB. Comparative evaluation of Amblyomma ovale ticks infected and noninfected by Rickettsia sp. strain Atlantic rainforest, the agent of an emerging rickettsiosis in Brazil. Ticks Tick-borne Dis. 2016;7:502-7.

23. Socolovschi C, Gaudart J, Bitam I, Huynh TP, Raoult D, Parola P. Why are there so few Rickettsia conorii conorii-infected Rhipicephalus sanguineus ticks in the wild? PLoS Negl Trop Dis. 2012;6:e1697.

24. Hunter DJ, Torkelson JL, Bodnar J, Mortazavi B, Laurent T, Deason J, et al. The Rickettsia endosymbiont of Ixodes pacificus contains all the genes of de novo folate biosynthesis. PLoS One. 2015;10:e0144552.

25. Bodnar JL, Fitch S, Rosati A, Zhong J. The folA gene from the Rickettsia endosymbiont of Ixodes pacificus encodes a functional dihydrofolate reductase enzyme. Ticks Tick-borne Dis. 2017;9:443-9.

26. Macaluso KR, Sonenshine DE, Ceraul SM, Azad AF. Rickettsial infection in Dermacentor variabilis (Acari: Ixodidae) inhibits transovarial transmission of a second Rickettsia. J Med Entomol. 2002;39:809-13.

27. Wright CL, Sonenshine DE, Gaff HD, Hynes WL. Rickettsia parkeri transmission to Amblyomma americanum by co-feeding with Amblyomma 
maculatum (Acari: Ixodidae) and potential for spillover. J Med Entomol. 2015;52(5):1090

28. Burgdorfer W, Hayes SF, Mavros AJ. Non-pathogenic rickettsiae in Dermacentor andersoni: a limiting factor for the distribution of Rickettsia rickettsii. In: Burgdorfer WAA, Anacker RL, editors. Rickettsia and Rickettsial Disease. New York: Academic Press; 1981. p. 585-94.

29. Gall CA, Reif KE, Scoles GA, Mason KL, Mousel M, Noh SM, et al. The bacterial microbiome of Dermacentor andersoni ticks influences pathogen susceptibility. ISME J. 2016;10:1846-55.

30. Bonnet SI, Binetruy F, Hernández-Jarguín AM, Duron O. The tick microbiome: why non-pathogenic microorganisms matter in tick biology and pathogen transmission. Front Cell Infect Microbiol. 2017;7:236.

31. Václav R, Ficová M, Prokop P, Betáková T. Associations between coinfection prevalence of Borrelia lusitaniae, Anaplasma sp., and Rickettsia sp. in hard ticks feeding on reptile hosts. Microb Ecol. 2011;61:245-53.

32. Lommano E, Bertaiola L, Dupasquier C, Gern L. Infections and coinfections of questing /xodes ricinus ticks by emerging zoonotic pathogens in western Switzerland. Appl Environ Microbiol. 2012;78:4606-12.

33. Driscoll TP, Verhoeve VI, Guillotte ML, Lehman SS, Rennoll SA, Beier-Sexton $\mathrm{M}$, et al. Wholly Rickettsia! Reconstructed metabolic profile of the quintessential bacterial parasite of eukaryotic cells. MBio. 2017;8:e00859-17.

34. Harris EK, Verhoeve VI, Banajee KH, Macaluso JA, Azad AF, Macaluso KR. Comparative vertical transmission of Rickettsia by Dermacentor variabilis and Amblyomma maculatum. Ticks Tick Borne Dis. 2017;8:598-604

35. Matsumoto K, Ogawa M, Brouqui P, Raoult D, Parola P. Transmission of Rickettsia massiliae in the tick, Rhipicephalus turanicus. Med Vet Entomol. 2005;19:263-70.

36. Davoust B, Mediannikov O, Marie JL, Socolovschi C, Parola P, Raoult D. Are vertebrates reservoir hosts for Rickettsia? Bull Acad Vet France. 2010; 163:291-302.

37. Levin ML, Snellgrove AN, Zemtsova GE. Comparative value of blood and skin samples for diagnosis of spotted fever group rickettsial infection in model animals. Ticks Tick Borne Dis. 2016;7:1029-34.

38. Haydon DT, Cleaveland S, Taylor LH, Laurenson MK. Identifying reservoirs of infection a conceptual and practical challenge. Emerg Infect Dis. 2002;8:1468-73.

39. Levin ML, Killmaster LF, Zemtsova GE. Domestic dogs (Canis familiaris) as reservoir hosts for Rickettsia conorii. Vector Borne Zoonotic Dis. 2012:12:28-33.

40. Burgdorfer W, Friedhoff KT, Lancaster Jr JL. Natural history of tick-borne spotted fever in the USA: Susceptibility of small mammals to virulent Rickettsia rickettsii. Bull World Health Organ. 1966;35:149-53.

41. Bozeman FM, Shirai A, Humphries JW, Fuller HS. Ecology of Rocky Mountain spotted fever II. Natural infection of wild mammals and birds in Virginia and Maryland. Am J Trop Med Hyg. 1967;16:48-59.

42. Burgdorfer W, Cooney JC, Mavros AJ, Jellison WL, Maser C. The role of cottontail rabbits (Sylvilagus spp.) in the ecology of Rickettsia rickettsii in the United States. Am J Trop Med Hyg. 1980;29:686-90.

43. Horta MC, Moraes-Filho J, Casagrande RA, Saito TB, Rosa SC, Ogrzewalska M, et al. Experimental infection of opossums Didelphis aurita by Rickettsia rickettsii and evaluation of the transmission of the infection to ticks Amblyomma cajennense. Vector Borne Zoonotic Dis. 2009;9:109-18.

44. Souza CE, Moraes-Filho J, Ogrzewalska M, Uchoa FC, Horta MC, Souza SS, et al. Experimental infection of capybaras Hydrochoerus hydrochaeris by Rickettsia rickettsii and evaluation of the transmission of the infection to ticks Amblyomma cajennense. Vet Parasitol. 2009:161:116-21.

45. Lukovsky-Akhsanov N, Keating MK, Spivey P, Lathrop Jr GW, Powell N, Levin ML. Assessment of domestic goats as models for experimental and natural infection with the North American isolate of Rickettsia slovaca. PLoS One. 2016;11:e0165007.

46. Heylen D, Fonville $M$, van Leeuwen AD, Sprong H. Co-infections and transmission dynamics in a tick-borne bacterium community exposed to songbirds. Env Microbiol. 2016;18:988-96.

47. Zemtsova G, Killmaster LF, Mumcuoglu KY, Levin ML. Co-feeding as a route for transmission of Rickettsia conorii israelensis between Rhipicephalus sanguineus ticks. Exp Appl Acarol. 2010;52:383-92.

48. Randolph SE, Gern L, Nuttall PA. Co-feeding ticks epidemiological significance for tick-borne pathogen transmission. Parasitol Today. 1996;12:472-9.

49. Levin ML, Zemtsova GE, Montgomery M, Killmaster LF. Effects of homologous and heterologous immunization on the reservoir competence of domestic dogs for Rickettsia conorii (israelensis). Ticks Tick Borne Dis. 2014;5:33-40.
50. Martello E, Selmi M, Ragagli C, Ambrogi C, Stella MC, Mannelli A, et al. Rickettsia slovaca in immature Dermacentor marginatus and tissues from Apodemus spp. in the northern Apennines, Italy. Ticks Tick Borne Dis. 2013;4:518-21.

51. Paddock CD, Allerdice MEJ, Karpathy SE, Nicholson WL, Levin ML, Smith TC, et al. Unique strain of Rickettsia parkeri associated with the hard tick Dermacentor parumapertus Neumann in the western United States. Appl Environ Microbiol. 2017;83.

52. Piranda EM, Faccini JLH, Pinter A, Saito TB, Pacheco RC, Hagiwara MK, et al. Experimental infection of dogs with a Brazilian strain of Rickettsia rickettsii clinical and laboratory findings. Mem Inst Oswaldo Cruz. 2008;103:696-701.

53. Labruna MB, Kamakura O, Moraes J, Horta MC, Pacheco RC. Rocky Mountain spotted fever in dogs, Brazil. Emerg Infect Dis. 2009;15:458-60.

54. Solano-Gallego L, Kidd L, Trotta M, Di Marco M, Caldin M, Furlanello T, et al. Febril illness associated with Rickettsia conorii infection in dogs from Sicily. Emerg Infect Dis. 2006;12:1985-9.

55. Alexandre N, Santos AS, Bacellar F, Boinas FJ, Nuncio MS, de Sousa R. Detection of Rickettsia conorii strains in Portuguese dogs (Canis familiaris). Ticks Tick Borne Dis. 2011;2:119-22.

56. Solano-Gallego L, Caprì A, Pennisi MG, Caldin M, Furlanello T, Trotta M. Acute febrile illness is associated with Rickettsia spp. infection in dogs. Parasit Vectors. 2015;8:216.

57. Curto P, Simões I, Riley SP, Martinez JJ. Differences in intracellular fate of two Spotted Fever Group Rickettsia in macrophage-like cells. Front Cell Infect Microbiol. 2016;6:80,

58. Mannelli A, Mandola ML, Pedri P, Tripoli M, Nebbia P. Associations between dogs that were serologically positive for Rickettsia conorii relative to the residences of two human cases of Mediterranean spotted fever in Piemonte (Italy). Prev Vet Med. 2003;60:13-26.

59. Demma LJ, Traeger M, Blau D, Gordon R, Johnson B, Dickson J, et al. Serologic evidence for exposure to Rickettsia rickettsii in eastern Arizona and recent emergence of Rocky Mountain spotted fever in this region. Vector Borne Zoonotic Dis. 2006;6:423-9.

60. McQuiston JH, Guerra MA, Watts MR, Lawaczeck E, Levy C, Nicholson WL, et al. Evidence of exposure to spotted fever group rickettsiae among Arizona dogs outside a previously documented outbreak area. Zoonoses Public Health. 2011:58:85-92

61. Wächter M, Wölfel S, Pfeffer M, Dobler G, Kohn B, Moritz A, et al. Serological differentiation of antibodies against Rickettsia helvetica, $R$. raoultii, $R$. slovaca, $R$. monacensis and $R$. felis in dogs from Germany by a microimmunofluorescent antibody test. Parasit Vectors. 2015;8:216.

62. Segura-Porta F, Diestre-Ortin G, Ortuño-Romero A, Sanfeliu-Sala I, Font-Creus B, Muñoz-Espin T, et al. Prevalence of antibodies to spotted fever group rickettsiae in human beings and dogs from and endemic area of Mediterranean spotted fever in Catalonia, Spain. Eur J Epidemiol. 1998;14:395-8.

63. Harrus S, Lior Y, Ephros M, Grisaru-Soen G, Keysary A, Strenger C, et al. Rickettsia conorii in humans and dogs a seroepidemiologic survey of two rural villages in Israel. Am J Trop Med Hyg. 2007;77:133-5.

64. Raoult D, Fournier PE, Eremeeva M, Graves S, Kelly PJ, Oteo JA, et al. Naming of Rickettsiae and rickettsial diseases. Ann N Y Acad Sci. 2005;1063:1-12.

65. Portillo A, de Sousa R, Santibáñez S, Duarte A, Edouard S, Fonseca IP, et al. Guidelines for the detection of Rickettsia spp. Vector Borne Zoonotic Dis. 2017;17:23-32.

66. Oteo JA, Ibarra V, Blanco JR, Martínez de Artola V, Márquez FJ, Portillo A, Raoult D, Anda P. Dermacentor-borne necrosis erythema and lymphadenopathy: clinical and epidemiological features of a new tick-borne disease. Clin Microbiol Infect. 2004;10:327-31.

67. Portillo A, Ibarra V, Santibáñez S, Pérez-Martínez L, Blanco JR, Oteo JA. Genetic characterisation of ompA, ompB and gltA genes from Ca. R. rioja. Clin Microbiol Infect. 2009;15(Suppl 2):307-8.

68. Pérez-Pérez L, Portillo A, Allegue F, Zulaica A, Oteo JA, Caeiro JL, et al. Dermacentor-borne Necrosis Erythema and Lymphadenopathy (DEBONEL): a case associated with Rickettsia rioja. Acta Derm Venereol. 2010;90:214-5.

69. Matsumoto K, Parola P, Rolain JM, Jeffery K, Raoult D. Detection of "Rickettsia sp. strain Uilenbergi" and "Rickettsia sp. strain Davousti" in Amblyomma tholloni ticks from elephants in Africa. BMC Microbiol. 2007;7:74.

70. Lopez-Velez R, Palomar AM, Oteo JA, Norman FF, Pérez-Molina JA, Portillo A. Novel Candidatus Rickettsia species detected in nostril tick from human, Gabon, 2014. Emerg Infect Dis. 2015;21:325-7.

71. Paddock CD, Sumner JW, Comer JA, Zaki SR, Goldsmith CS, Goddard J. Rickettsia parkeri a newly recognized cause of spotted fever rickettsiosis in the United States. Clin Infect Dis. 2004;38:805-11. 
72. Portillo A, Oteo JA. New tools, new tick-borne diseases? World J Clin Infect Dis. 2015;5:51-4.

73. Medlock JM, Hansford KM, Bormane A, Derdakova M, Estrada-Peña A, George JC, et al. Driving forces for changes in geographical distribution of Ixodes ricinus ticks in Europe. Parasit Vectors. 2013;6:1.

74. Karbowiak G. The occurrence of the Dermacentor reticulatus tick - its expansion to new areas and possible causes. Ann Parasitol. 2014;60:37-47.

75. Oteo JA, Portillo A. Tick-borne rickettsioses in Europe. Ticks Tick Borne Dis. 2012;3:271-8.

76. Parola P, Socolovschi C, Jeanjean L, Bitam I, Fournier PE, Sotto A, et al. Warmer weather linked to tick attack and emergence of severe rickettsioses. PLoS Negl Trop Dis. 2008;2:e338.

77. Millán J, Proboste T, Fernández de Mera IG, Chirife AD, de la Fuente J, Altet L. Molecular detection of vector-borne pathogens in wild and domestic carnivores and their ticks at the human-wildlife interface. Ticks Tick Borne Dis. 2016;7:284-90.

78. Pesquera C, Portillo A, Palomar AM, Oteo JA. Investigation of tick-borne bacteria (Rickettsia spp., Anaplasma spp., Ehrlichia spp. and Borrelia spp.) in ticks collected from Andean tapirs, cattle and vegetation from a protected area in Ecuador. Parasit Vectors. 2015;8:46.

79. Palomar AM, Santibáñez P, Mazuelas D, Roncero L, Santibáñez S, Portillo A, et al. Role of birds in dispersal of etiologic agents of tick-borne zoonoses, Spain, 2009. Emerg Infect Dis. 2012;18:1188-91.

80. Sparagano O, George D, Giangaspero A, Špitalská E. Arthropods and associated arthropod-borne diseases transmitted by migrating birds. The case of ticks and tick-borne pathogens. Vet Parasitol. 2015;213:61-6.

81. Randolph SE. To what extent has climate change contributed to the recent epidemiology of tick-borne diseases? Vet Parasitol. 2010;167:92-4.

82. Portillo A, Oteo JA. Rickettsiosis as threat for the traveller. In: Rodriguez-Morales A, editor. Current Topics in Tropical Medicine. Rijeka: InTech; 2012. p. 3-24.

83. Pietzsch ME, Hansford KM, Cull B, Jahfari S, Sprong H, Medlock JM. Detection of Dermacentor marginatus and a possible Rickettsia slovaca case in the United Kingdom-the risk of the visiting traveller. Travel Med Infect Dis. 2015;13:200-1.

84. Jahfari S, de Vries A, Rijks JM, Van Gucht S, Vennema H, Sprong H, et al. Tick-borne encephalitis virus in ticks and roe deer, the Netherlands. Emerg Infect Dis. 2017;23:1028-30.

85. de Graaf JA, Reimerink JH, Voorn GP, Bij de Vaate EA, de Vries A, Rockx B, et al. First human case of tick-borne encephalitis virus infection acquired in the Netherlands, July 2016. Euro Surveill. 2016;21:30318.

86. Weststrate AC, Knapen D, GD Laverman BS, Prick JJ, Spit SA, et al. Increasing evidence of tick-borne encephalitis (TBE) virus transmission, the Netherlands, June 2016. Euro Surveill. 2017;22:30482.

87. García Rada A. First outbreak of Crimean-Congo haemorrhagic fever in western Europe kills one man in Spain. BMJ. 2016;354:14891.

88. Estrada-Peña A, Palomar AM, Santibáñez P, Sánchez N, Habela MA, Portillo $A$, et al. Crimean-Congo hemorrhagic fever virus in ticks, southwestern Europe, 2010. Emerg Infect Dis. 2012;18:179-80.

89. European Centre for Disease Prevention and Control. Epidemiological situation of rickettsioses in EU/EFTA countries. Stockholm: ECDC; 2013. https://ecdc.europa.eu/en/publications-data/epidemiological-situationrickettsioses-euefta-countries. Accessed 18 Jan 2018.

90. Stärk KD, Arroyo Kuribreña M, Dauphin G, Vokaty S, Ward MP, Wieland $B$, et al. One Health surveillance - More than a buzz word? Prev Vet Med. 2015;120:124-30.

91. Dietrich M, Lebarbenchon C, Jaeger A, Le Rouzic C, Bastien M, Lagadec E, et al. Rickettsia spp. in seabird ticks from western Indian Ocean islands, 20112012. Emerg Infect Dis. 2014;20:838-42.

92. Reeves WK, Loftis AD, Sanders F, Spinks MD, Wills W, Denison AM, et al. Borrelia, Coxiella, and Rickettsia in Carios capensis (Acari, Argasidae) from a brown pelican (Pelecanus occidentalis) rookery in South Carolina, USA. Exp Appl Acarol. 2006;39:321-9.

93. Pader V, Nikitorowicz Buniak J, Abdissa A, Adamu H, Tolosa T, Gashaw A, et al. Candidatus Rickettsia hoogstraalii in Ethiopian Argas persicus ticks. Ticks Tick Borne Dis. 2012;3:338-45.

94. Kawabata H, Ando S, Kishimoto T, Kurane I, Takano A, Nogami S, et al. First detection of Rickettsia in soft-bodied ticks associated with seabirds, Japan. Microbiol Immunol. 2006;50:403-6.

95. Mattila JT, Burkhardt NY, Hutcheson HJ, Munderloh UG, Kurtt TJ. Isolation of cell lines and a rickettsial endosymbiont from the soft tick Carios capensis (Acari Argasidae Ornithodorinae). J Med Entomol. 2007;44:1091-101.
96. Milhano N, Palma M, Marcili A, Núncio MS, de Carvalho IL, de Sousa R. Rickettsia lusitaniae sp. nov. isolated from the soft tick Ornithodoros erraticus (Acarina Argasidae). Comp Immunol Microbiol Infect Dis. 2014;37:189-93.

97. Sánchez-Montes S, Guzmán-Cornejo C, Martínez-Nájera Y, Becker I, Venzal JM, Labruna MB. Rickettsia lusitaniae associated with Ornithodoros yumatensis (Acari: Argasidae) from two caves in Yucatan, Mexico. Ticks Tick Borne Dis. 2016;7:1097-101.

98. Moreira-Soto RD, Moreira-Soto A, Corrales-Aguilar E, Calderón-Arguedas Ó, Troyo A. 'Candidatus Rickettsia nicoyana': A novel Rickettsia species isolated from Ornithodoros knoxjonesi in Costa Rica. Ticks Tick Borne Dis. 2017;8:532-6

99. Tahir D, Socolovschi C, Marié JL, Ganay G, Berenger JM, Bompar JM, et al. New Rickettsia species in soft ticks Ornithodoros hasei collected from bats in French Guiana. Ticks Tick Borne Dis. 2016;7:1089-96.

100. Řeháček J, Urvölgyi J, Kovácová E. Massive occurrence of rickettsiae of the spotted fever group in fowl tampan, Argas persicus, in the Armenian SSR. Acta Virol. 1977;21:431-8.

101. Socolovschi C, Kernif T, Raoult D, Parola P. Borrelia, Rickettsia, and Ehrlichia species in bat ticks, France, 2010. Emerg Infect Dis. 2012;18:1966-75.

102. Lafri I, Leulmi H, Baziz-Neffah F, Lalout R, Mohamed C, Mohamed K, et al. Detection of a novel Rickettsia sp. in soft ticks (Acari Argasidae) in Algeria. Microbes Infect. 2015;17:859-61.

103. Loftis AD, Gill JS, Schriefer ME, Levin ML, Eremeeva ME, Gilchrist MJ, et al. Detection of Rickettsia, Borrelia, and Bartonella in Carios kelleyi (Acari: Argasidae). J Med Entomol. 2005;42:473-80.

104. Cutler SJ, Browning P, Scott JC. Ornithodoros moubata, a soft tick vector for Rickettsia in East Africa? Ann N Y Acad Sci. 2006;1078:373-7.

105. Burgdorfer W, Newhouse VF, Pickens EG, Lackman DB. Ecology of Rocky Mountain spotted fever in Western Montana I. Isolation of Rickettsia rickettsii from wild mammals. Am J Hyg. 1962;76:293-301.

106. Moreira JA, Magalhães O. Thypho exanthematico em Minas Gerais. BrasilMédico. 1935:44:465-70.

107. Travassos J. Identification d'un virus semblable a celui du "Typhus exanthématique de Sao Paulo," isolé de la sarigue marsupiale (Didelphis paraguayensis). Compt Rend Soc Biol. 1937;126:1054-6.

108. Ueno TE, Costa FB, Moraes-Filho J, Agostinho WC, Fernandes WR, Labruna MB. Experimental infection of horses with Rickettsia rickettsii. Parasit Vectors. 2016;9:499.

109. Horta MC, Sabatini GS, Moraes-Filho J, Ogrzewalska M, Canal RB, Pacheco $\mathrm{RC}$, et al. Experimental infection of the opossum Didelphis aurita by Rickettsia felis, Rickettsia bellii, and Rickettsia parkeri and evaluation of the transmission of the infection to ticks Amblyomma cajennense and Amblyomma dubitatum. Vector Borne Zoonotic Dis. 2010;10:959-67.

110. Tomassone L, Conte V, Parrilla G, De Meneghi D. Rickettsia infection in dogs and Rickettsia parkeri in Amblyomma tigrinum ticks, Cochabamba Department, Bolivia. Vector Borne Zoonotic Dis. 2010;10:953-8.

111. Grasperge BJ, Wolfson W, Macaluso KR. Rickettsia parkeri infection in domestic dogs, Southern Louisiana, USA, 2011. Emerg Infect Dis. 2012;18:995-7.

112. Joyeux C, Pieri J. Le lapin peut constituer un réservoir de virus pour la fièvre boutonneuse (exanthématique). C R Acad Sci. 1932;194:2342.

113. Ruiz-Beltrán R, Herrero-Herrero Jl, Martín- Sanchez AM, Criado-Gutiérrez LA. Role of Lagomorpha in the wild cycle of Rickettsia conorii in Salamanca (Spain). Eur J Epidemiol. 1992;8:136-9.

114. Segura F, Pons I, Miret J, Pla J, Ortuño A, Nogueras MM. The role of cats in the eco-epidemiology of spotted fever group diseases. Parasit Vectors. 2014;7:353.

115. Dietrich M, Tjale MA, Weyer J, Kearney T, Seamark EC, Nel LH, et al. Diversity of Bartonella and Rickettsia spp. in bats and their blood-feeding ectoparasites from South Africa and Swaziland. PLoS One. 2016;11:e0152077.

116. Inokuma H, Seino N, Suzuki M, Kaji K, Takahashi H, Igota H, et al. Detection of Rickettsia helvetica DNA from peripheral blood of sika deer (Cervus nippon yesoensis) in Japan. J Wild Dis. 2008;44:164-7.

117. Sprong H, Wielinga PR, Fonville M, Reusken C, Brandenburg AH, Borgsteede $F$, et al. Ixodes ricinus ticks are reservoir hosts for Rickettsia helvetica and potentially carry flea-borne Rickettsia species. Parasit Vectors. 2009;2:41.

118. Hornok S, Kováts D, Csörgő T, Meli ML, Gönczi E, Hadnagy Z, et al. Birds as potential reservoirs of tick-borne pathogens first evidence of bacteraemia with Rickettsia helvetica. Parasit Vectors. 2014;7:128.

119. Speck S, Perseke L, Petney T, Skuballa J, Pfäffle M, Taraschewski H, et al. Detection of Rickettsia helvetica in ticks collected from European hedgehogs (Erinaceus europaeus Linnaeus, 1758). Ticks Tick Borne Dis. 2013;4:222-6. 
120. De Sousa R, Lopes de Carvalho I, Santos AS, Bernardes C, Milhano N, Jesus J, et al. Role of the lizard Teira dugesii as a potential host for Ixodes ricinus tickborne pathogens. Appl Environ Microbiol. 2012;78:3767-9.

121. Tomassone L, Ceballos LA, Ragagli C, Martello E, de Sousa R, Stella MC, et al. Importance of common wall lizards in the transmission dynamics of tickborne pathogens in the northern Apennine Mountains, Italy. Microb Ecol. 2017;74:961-8

122. Schex S, Dobler G, Riehm J, Müller J, Essbauer S. Rickettsia spp. in wild small mammals in Lower Bavaria, south-eastern Germany. Vector Borne Zoonotic Dis. 2011;11:493-502.

123. Schmidt S, Essbauer SS, Mayer-Scholl A, Poppert S, Schmidt-Chanasit J Klempa B, et al. Multiple infections of rodents with zoonotic pathogens in Austria. Vector Borne Zoonotic Dis. 2014;14:467-75.

124. Hornok S, Földvári G, Rigó K, Meli ML, Gönczi E, Répási A, et al. Synanthropic rodents and their ectoparasites as carriers of a novel haemoplasma and vector-borne, zoonotic pathogens indoors. Parasit Vectors. 2015;8:27.

125. Lauzi S, Maia JP, Epis S, Marcos R, Pereira C, Luzzago C, et al. Molecular detection of Anaplasma platys, Ehrlichia canis, Hepatozoon canis and Rickettsia monacensis in dogs from Maio Island of Cape Verde archipelago. Ticks Tick-borne Dis. 2016;7:964-9.

126. Liesner JM, Krucken J, Schaper R, Pachnicke S, Kohn B, Muller E, et al. Vectorborne pathogens in dogs and red foxes from the federal state of Brandenburg, Germany. Vet Parasitol. 2016;224:44-51.

127. Řeháček J, Urvölgyi J, Kocianová E, Jedlička L. Susceptibility of some species of rodents to rickettsiae. Folia Parasitol (Praha). 1992;39:265-84.

128. Márquez FJ, Rojas A, Ibarra V, Cantero A, Rojas J, Oteo JA, et al. Prevalence data of Rickettsia slovaca and other SFG rickettsiae species in Dermacentor marginatus in the southeastern Iberian Peninsula. Ann N Y Acad Sci. 2006; 1078:328-30.

129. Ortuño A, Quesada M, Lopez-Claessens S, Castella J, Sanfeliu I, Anton E, et al. The role of wild boar (Sus scrofa) in the ecoepidemiology of $R$. slovaca in northeastern Spain. Vector Borne Zoonotic Dis. 2007;7:59-64.

130. Selmi M, Martello E, Bertolotti L, Bisanzio D, Tomassone L. Rickettsia slovaca and Rickettsia raoultii in Dermacentor marginatus ticks collected on wild boars (Sus scrofa) in Tuscany, Italy. J Med Entomol. 2009;46:1490-3.

131. Ortuño A, Pons I, Quesada M, Lario S, Anton E, Gil A, et al. Evaluation of the presence of Rickettsia slovaca infection in domestic ruminants in Catalonia, Northeastern Spain. Vector Borne Zoonotic Dis. 2012;12:1019-22.

132. Shpynov S, Fournier PE, Rudakov N, Raoult D. "Ca. R. tarasevichiae" in Ixodes persulcatus ticks collected in Russia. Ann N Y Acad Sci. 2003;990:162-72.

133. Jia N, Zheng YC, Jiang JF, Ma L, Cao WC. Human infection with Candidatus Rickettsia tarasevichiae. N Engl J Med. 2013;369:1178-80.

134. Sréter-Lancz Z, Széll Z, Kovács G, Egyed L, Márialigeti K, Sréter T. Rickettsiae of the spotted-fever group in ixodid ticks from Hungary: identification of a new genotype ('Ca. R. kotlanii'). Ann Trop Med Parasitol. 2006;100:229-36.

135. Mura A, Masala G, Tola S, Satta G, Fois F, Piras P, et al. First direct detection of rickettsial pathogens and a new rickettsia, 'Candidatus Rickettsia barbariae', in ticks from Sardinia, Italy. Clin Microbiol Infect. 2008;14:1028-33.

136. Eremeeva ME, Stromdahl EY. New spotted fever group Rickettsia in a Rhipicephalus turanicus tick removed from a child in eastern Sicily, Italy. Am J Trop Med Hyg. 2011;84:99-101.

137. Igolkina YP, Rar VA, Yakimenko W, Malkova MG, Tancev AK, Tikunov AY, et al. Genetic variability of Rickettsia spp. in Ixodes persulcatus/lxodes trianguliceps sympatric areas from Western Siberia, Russia: identification of a new Candidatus Rickettsia species. Infect Genet Evol. 2015;34:88-93.

138. Hajduskova E, Literak I, Papousek I, Costa FB, Novakova M, Labruna MB, et al. 'Candidatus Rickettsia mendelii', a novel basal group rickettsia detected in Ixodes ricinus ticks in the Czech Republic. Ticks Tick Borne Dis. 2016;7:482-6.

139. Jiang J, Blair PJ, Felices V, Moron C, Cespedes M, Anaya E, et al. Phylogenetic analysis of a novel molecular isolate of spotted fever group Rickettsiae from northern Peru: Candidatus Rickettsia andeanae. Ann N Y Acad Sci. 2005;1063:337-42.

140. Rolain JM, Mathai E, Lepidi H, Somashekar HR, Mathew LG, Prakash JA, et al. "Ca. R. kellyi", India. Emerg Infect Dis. 2006;12:483-5.

141. Mediannikov O, Sidelnikov Y, Ivanov L, Fournier PE, Tarasevich I, Raoult D. Far eastern tick-borne rickettsiosis: identification of two new cases and tick vector. Ann N Y Acad Sci. 2006;1078:80-8.

142. Izzard L, Graves S, Cox E, Fenwick S, Unsworth N, Stenos J. Novel rickettsia in ticks, Tasmania, Australia. Emerg Infect Dis. 2009;15:1654-6.

143. Tomassone L, Nuñez P, Ceballos LA, Gürtler RE, Kitron U, Farber M. Detection of "Ca. R. sp. strain Argentina" and Rickettsia bellii in
Amblyomma ticks (Acari: Ixodidae) from Northern Argentina. Exp Appl Acarol. 2010;52:93-100.

144. Williamson PC, Billingsley PM, Teltow GJ, Seals JP, Turnbough MA, Atkinson SF. Borrelia, Ehrlichia, and Rickettsia spp. in ticks removed from persons, Texas, USA. Emerg Infect Dis. 2010;16:441-6.

145. Zou Y, Wang Q, Fu Z, Liu P, Jin H, Yang H, et al. Detection of spotted fever group Rickettsia in Haemaphysalis longicornis from Hebei Province, China. J Parasitol. 2011;97:960-2.

146. Mediannikov O, Diatta G, Zolia Y, Balde MC, Kohar H, Trape JF, et al. Tickborne rickettsiae in Guinea and Liberia. Ticks Tick Borne Dis. 2012;3:43-8.

147. Mutai BK, Wainaina JM, Magiri CG, Nganga JK, Ithondeka PM, Njagi ON, et al Zoonotic surveillance for rickettsiae in domestic animals in Kenya. Vector Borne Zoonotic Dis. 2013;13(6):360.

148. Anstead CA, Chilton NB. A novel Rickettsia species detected in vole ticks (Ixodes angustus) from western Canada. Appl Environ Microbiol. 2013;79: 7583-9.

149. Anstead CA, Chilton NB. Detection of a novel Rickettsia (Alphaproteobacteria: Rickettsiales) in rotund ticks (Ixodes kingi) from Saskatchewan, Canada. Ticks Tick Borne Dis. 2013:4:2012-6.

150. Mediannikov O, Aubadie-Ladrix M, Raoult D. Candidatus 'Rickettsia senegalensis' in cat fleas in Senegal. New Microbes New Infect. 2014;3:24-8.

151. Kho KL, Koh FX, Tay ST. Molecular evidence of potential novel spotted fever group rickettsiae, Anaplasma and Ehrlichia species in Amblyomma ticks parasitizing wild snakes. Parasit Vectors. 2015;8:112.

152. Ereqat S, Nasereddin A, Al-Jawabre hA, Azmi K, Harrus S, Mumcuoglu K, et al. Molecular detection and identification of Spotted Fever Group rickettsiae in ticks collected from the West Bank, Palestinian territories. PLoS Negl Trop Dis. 2016;10:e0004348

153. Yang J, Tian Z, Liu Z, Niu Q, Han R, Li Y, et al. Novel spotted fever group rickettsiae in Haemaphysalis qinghaiensis ticks from Gansu, Northwest China. Parasit Vectors. 2016;9:146

154. Takajo I, Sekizuka T, Fujita H, Kawano A, Kawaguchi T, Matsuda M, et al. Possible case of novel spotted fever group rickettsiosis in traveler returning to Japan from India. Emerg Infect Dis. 2016;22:1079-82.

155. Kimita G, Mutai B, Nyanjom SG, Wamunyokoli F, Waitumbi J. Phylogenetic variants of Rickettsia africae, and incidental identification of "Candidatus Rickettsia moyalensis" in Kenya. PLoS Negl Trop Dis. 2016;10:e0004788.

156. Sabatini GS, Pinter A, Nieri-Bastos FA, Marcili A, Labruna MB. Survey of ticks (Acari: Ixodidae) and their rickettsia in an Atlantic rain forest reserve in the State of São Paulo, Brazil. J Med Entomol. 2010;47:913-6.

157. Spolidorio MG, Labruna MB, Mantovani E, Brandao PE, Richtzenhain $L$, Yoshinari NH. Novel spotted fever group rickettsiosis, Brazil. Emerg Infect Dis. 2010;16(3):521.

158. Almeida AP, Cunha LM, Bello AC, da Cunha AP, Domingues LN, Leite RC, et al. A novel Rickettsia infecting Amblyomma dubitatum ticks in Brazil. Ticks Tick Borne Dis. 2011;2:209-12.

159. Miranda J, Portillo A, Oteo JA, Mattar S. Rickettsia sp. strain colombianensi (Rickettsiales: Rickettsiaceae): a new proposed Rickettsia detected in Amblyomma dissimile (Acari: Ixodidae) from iguanas and free-living larvae ticks from vegetation. J Med Entomol. 2012;49:960-5.

160. Dubska L, Literak I, Kverek P, Roubalova E, Kocianova E, Taragelova V. Tickborne zoonotic pathogens in ticks feeding on the common nightingale including a novel strain of Rickettsia sp. Ticks Tick Borne Dis. 2012;3:265-8.

161. Sandalakis V, Chochlakis D, loannou I, Psaroulaki A. Identification of a novel uncultured Rickettsia species strain (Rickettsia species strain Tselenti) in Cyprus. Am J Trop Med Hyg. 2013;88:698-700.

162. Troyo A, Moreira-Soto A, Carranza M, Calderón-Arguedas O, Hun L, Taylor L. Detection of an undescribed Rickettsia sp. in Ixodes boliviensis from Costa Rica. Ticks Tick Borne Dis. 2014:5(6):883. 